\title{
PERAN KOMPENSASI FINANSIAL DAN KOMPENSASI NON FINANSIAL DALAM MENINGKATKAN PRODUKTIVITAS KERJA PEGAWAI NEGERI SIPIL PADA DINAS SOSIAL KOTA BANJARMASIN
}

\author{
Khairunnisa \\ incess.nissa@gmail.com \\ STIE Pancasetia Banjarmasin
}

\begin{abstract}
Research purposes for knowing role financial and non financial compensations in upgrade work productivity of Pegawai Negeri Sipil on Dinas Sosial Kota Banjarmasin. Component of compensation consists of salary, wage, incentive and fringe benefit. Population in this research amount 35 peoples and sample 20 peoples. Explenation tittle among them, compensation is all income being of money, direct goods or undirect receive of employes are reward or service given to agency. Work productivity is ratio between result achieved with role participation of labour unity of time. Dinas Sosial Kota Banjarmasin is agency of government to manage matter society, as help social to disaster, religion, etc.

Key Words : Financial Compensation, Non Financial Compensation, Work Productivity.
\end{abstract}

\section{Pendahuluan}

Sejak dahulu kita sudah mengenal adanya berbagai bentuk penghargaan yang diberikan instansi kepada pegawainya. Hubungan antara pegawai dan instansi pada dasarnya adalah hubungan timbal balik.

Disatu sisi, pegawai yang bekerja pada sebuah instansi mempunyai kontribusi berupa tenaga dan pikiran untuk membuat instansi menjadi lebih maju dan berkembang. Disisi lain, instansi juga mempunyai kewajiban terhadap pegawainya dengan memberikan imbalan yang sepadan agar lebih meningkatkan produktivitas kerjanya.

Ada 2 bentuk penghargaan yang diberikan instansi Dinas Sosial Kota Banjarmasin kepada pegawai, mulai dari hal yang sangat sederhana, misalnya hanya berupa senyuman dan pujian, sampai yang berbentuk uang, misalnya kenaikan gaji, honor maupun tunjangan-tunjangan lain yang bersifat finansial.

Selain sebagai sebuah bentuk penghargaan yang diberikan kepada pegawainya, pemberian penghargaan ini dimaksudkan untuk memberikan motivasi kepada pegawai agar mereka merasa nyaman dan lebih produktif dalam bekerja.

Tetapi pada kenyataan yang kita jumpai dalam kehidupan nyata, tidak semua penghargaan mempunyai pengaruh yang sama dalam memotivasi setiap pegawai. Misalnya saja ada pegawai yang merasa senang hanya dengan diberikan senyuman dan pujian. Tetapi, tidak sedikit pegawai yang menuntut diberikan penghargaan mulai darii mbalan finansial bahkan lebih kepada imbalan non finansial. Karena menurut mereka ada hal yang lebih penting lagi, misalnya pemberian honor yang besar dalam melaksanakan proyek kerja sampai kebutuhan akan kendaraan dinas.

Setiap pegawai pasti menginginkan suatu bentuk penghargaan yang lebih bersifat riil. Bukan hanya sebuah senyuman atau pujian semata,karena mereka menginginkan sesuatu yang dapat dirasakan manfaatnya. Salah satu bentuk penghargaan yang dapat benar-benar dirasakan oleh pegawai adalah penghargaan dalam bentuk promosi jabatan. Sehingga dalam hal ini pimpinan perlu berhati-hati dalam mengambil sebuah keputusan dalam pemberian penghargaan kepada pegawainya. Informasi mengenai bentuk-bentuk penghargaan sangat dibutuhkan agar tidak terjadi kesalahan yang berakibat fatal bagi keberlangsungan pegawai.

Berdasarkan uraian diatas maka variabel kompensasi dan variabel produktivitas kerja memiliki hubungan yang cukup erat tidak hanya pada instansi Dinas Sosial Kota Banjarmasin, tetapi juga sangat diperlukan oleh instansi maupun perusahaan dan organisasi lain,sehingga peneliti mengangkat judul penelitian ini "Peran Kompensasi Finansial dan Kompensasi Non Finansial dalam Meningkatkan Produktivitas 
Kerja Pegawai Negeri Sipil pada Dinas Sosial Kota Banjarmasin”.

\section{Rumusan Masalah}

Rumusan masalah pada penelitian ini, sebagai berikut : Bagaimana peran kompensasi finansial dan kompensasi non finansial dalam meningkatkan produktivitas kerja Pegawai Negeri Sipil pada Dinas Sosial Kota Banjarmasin?

\section{Tujuan Penelitian}

Tujuan penelitian ini untuk : Mengetahui peranan kompensasi finansial dan kompensasi non finansial dalam meningkatkan produktivitas kerja Pegawai Negeri Sipil pada Dinas Sosial Kota Banjarmasin.

\section{Tinjauan Teoritis}

Manulang dalam Mailiana (2010 : 138) menyimpulkan bahwa kompensasi memungkinkan (pegawai) mempertahankan taraf hidup yang wajar dan layak serta hidup mandiri tanpa menggantungkan pemenuhan berbagai jenis kebutuhannya pada orang lain.

Kompensasi merupakan sesuatu yang diterima pegawai (karyawan) sebagai pengganti kontribusi jasa mereka pada perusahaan (Rivai, $2004: 357)$.

Kompensasi (imbalan) adalah elemen kritis dalam setiap strategi organisasi terutama dalam rangka memotivasi pegawai. Untuk memotivasi, imbalan haruslah bernilai dimata pegawai dan distribusinya harus adil (Ardhana, dkk, 2008 : 143).

Menurut Samsudin (2006: 187) Kompensasi mengandung arti yang lebih luas daripada upah dan gaji. Upah atau gaji lebih menekankan pada balas jasa yang bersifat finansial, sedangkan kompensasi mencakup balas jasa finansial maupun non finansial.

Kompensasi merupakan pemberian balas jasa, baik secara langsung berupa uang (finansial) maupun tidak langsung berupa penghargaan (non finansial).

Kompensasi yang memadai dengan membandingkan antara kontribusi yang diberikan pegawai bagi instansi dengan imbalan memadai yang pegawai terima akan berimplikasi pada loyalitas pegawai dalam bekerja pada instansitersebut.

Kompensasi yang tidak memadai akan berakibat buruk bagi pegawai, karena berimplikasipada mengurangnya produktivitas pegawai, pemogokan kerja, demo, perlakuan anarkis dan lain sebagainya.

Kompensasi yang berlebih juga akan berimplikasi tidak baik bagi instansi, karena pegawai tidak mengalami tantangan dalam bekerja, malas, pegawai tidak ada upaya untuk meningkatkan produktivitasnya, kurangnya kompetisi dan lain sebagainya.

Komponen-komponen kompensasi menurut Rivai (2004 : 360) dibedakan atas :

1. Gaji

Gaji adalah balas jasa dalam bentuk uang yang diterima karyawan sebagai konsekuensi dari kedudukannya sebagai seorang karyawan yang memberikan sumbangan tenaga dan pikiran dalam mencapai tujuan perusahaan.

2. Upah

Upah adalah imbalan langsung yang dibayarkan kepada karyawan berdasarkan jam kerja, jumlah barang yang dihasilkan atau banyaknya pelayanan yang diberikan.

3. Insentif

Insentif adalah imbalan langsung yang dibayarkan kepada karyawan karena kinerjanya melebihi standar yang ditentukan.

4. Kompensasi Tidak Langsung (Fringe Benefit)

Kompensasi tidak langsung (fringe benefit) adalah kompensasi tambahan yang diberikan berdasarakan kebijakan perusahaan terhadap semua karyawan sebagai upaya meningkatkan kesejahteraan para karyawan.

Pengertian produktivitas menurut Robbins (2003 : 28) yaitu ukuran kinerja yang mencakup efektivitas dan efisiensi.

Beberapa pakar pada umumnya sependapat bahwa produktivitas adalah "output per unit, atau output dibagi input, atau rasio antara output dengan input" (Sutrisno, 2010 : 207).

Seseorang seringkali tidak menyadari bahwa faktor penentu yang memacu produktivitas suatu organisasi adalah faktor manusia dan lingkungannya. Faktor manusia 
akan memunculkan perilaku yang produktif dalam memberikan kontribusi yang besar bagi organisasi dan bagi dirinya sendiri.

Produktivitas memiliki dua dimensi. Dimensi pertama yaitu efektivitas, dimensi ini mengarah pada pencapaian unjuk kerja yang maksimal yaitu meliputi kualitas, kuantitas dan waktu. Dimensi kedua yaitu efisiensi yang berkaitan dengan upaya membandingkan input dengan realisasi penggunaannya atau bagaimana pekerjaan tersebut dilaksanakan.

Pribadiyono dan $\operatorname{Arif}(2002$ : 10) menguraikan efektivitas sebagai suatu ukuran seberapa baik atau seberapa jauh sasaran telah dicapai.

Definisi efektivitas menurut Robbins (2003 : 28) adalah pencapaian tujuan. Efektivitas sering disebut hasil guna. Konsep efektivitas berorientasi pada keluaran bukan pada masukan. Efektivitas yang tinggi belum tentu efisien.

Suatu proses dikatakan lebih efektif bila dengan masukan yang sama menghasilkan keluaran yang lebih besar, hasil yang lebih baik dan dalam waktu yang lebih singkat.

Efisien adalah seberapa baik sumbersumber daya digunakan untuk menghasilkan suatu hasil, sehingga makin besar masukan dapat dihemat maka makin tinggi tingkat efisiensinya (Pribadiyono dan Arif, 2002 : 10).

Pengertian efisiensi menurut Robbins (2003 : 28) adalah nisbah antara keluaran efektif dan masukan yang diperlukan untuk mencapainya. Perilaku efektif akan menghasilkan kinerja yang sesuai dengan rencana. Perilaku efisiensi akan menggunakan sumberdaya dengan baik, sehingga kinerjanya akan melebihi sumberdaya yang digunakan.

\section{Metode Penelitian}

Penjelasan judul pada penelitian ini, sebagai berikut :

1. Kompensasi yaitu :semua pendapatan dalam bentuk uang, barang langsung atau tidak langsung yang diterima pegawai sebagai imbalan atas jasa yang diberikan kepada instansi.

2. Produktivitas kerja yaitu : perbandingan antara hasil yang dicapai dengan peran serta tenaga kerja per satuan waktu

3. Dinas Sosial Kota Banjarmasin yaitu : instansi pemerintah yang mengelola urusan kemasyarakatan, seperti bantuan sosial untuk bencana, keagamaan dan lain-lain.

Populasi

Populasi pada penelitian ini berjumlah 35

orang, 15 orang pegawai kontrak dan 20 orang pegawai Negeri Sipil

\section{Sampel}

Sampel pada penelitian ini berjumlah 20 orang

dan 5 orang pegawai yang melakukan

wawancara seputar tema yang diangkat.

\section{HASIL PENELITIAN DAN} PEMBAHASAN

Kompensasi Finansial

a. Gaji

Kompensasi finansial berupa gaji yang diterima pegawai Dinas Sosial Kota Banjarmasin.khususnya pegawai yang sudah berkeluarga,dimana gaji yang mereka terima selama sebulan secara nominal masih dirasa kurang,seandainya dirasa cukup tetapi dengan konsekuensi dalam memenuhi kebutuhan hidup keluarga sehari-hari dijalankan dengan pola hidup sederhana, akan tetapi bagi pegawai yang masih lajang, gaji yang diterima setiap bulan secara nominal besarannya sudah cukup sesuai untuk memenuhi kebutuhan hidup sehari-hari.

Permasalahan yang terjadi adalah setiap individu secara manusiawi tentu ingin hidup layak, hal ini yang mendasari seseorang mencari pekerjaan, disamping itu setiap individu hidup bersosialisasi dan ingin mendapatkan pengakuan dari orang lain tentang derajat kemapanan mereka. Pegawai juga inginmemenuhi kebutuhan hidup sekunder mereka seperti mengambil kredit perumahan, fasilitas transpotrasi yang memadai seperti sepeda motor dan mobil, biaya pendidikan anak dan lain-lain. sehingga untuk memenuhi kebutuhan tersebut pegawai terpaksa harus meminjam dana kepada pihak Bank, koperasi maupun lembaga keuangan lain. Disamping itu,perolehangaji masih dirasakurang dikarenakan persentase kenaikan pertahunnya tidak sesuai dengan kenaikan 
harga kebutuhan bahan pokok yang semakin melambung.

b. Tunjangan

Tunjangan jabatan yang diterima pegawai berdasarkan pangkat, jabatan, golongan, pendidikan dan masa kerja pegawai serta berdasarkan daftar yang telah diberikan pemerintah. Melihat hal itu, sebagian pegawai ada yang berlomba-lomba meningkatkan strata pendidikannya ke jenjang yang lebih tinggi, tetapi sebagian lagi tidak termotivasi kuliah, dikarenakan kurangnya biaya, tidak ada bantuan dari instansi ini berupa bantuan bea siswa atau bantuan pendidikan lainnya, sehingga pegawai tersebut harus mengeluarkan biaya sendiri, disamping mereka juga memerlukan biaya untuk kebutuhan hidup sehari-hari.

c. Honor

Dalam setahun biasanya beberapa bidang pada Dinas Sosial Kota Banjarmasin melaksanakan beberapa proyek kerja. Sebelum proyek tersebut dilaksanakan, instansi ini harus mengajukan persetujuan anggaran kepada anggota Dewan Kota, dimana dana tersebut berasal dari APBD Kota, ketika proyek tersebut disetujui, baru pelaksanaannya dapat dilakukan oleh semua bidang baik bersama-sama maupun sendiri-sendiri secara bergiliran. Setiap proyek besaran nominalnya berbedabeda. semua itu tergantung dari besaran anggaran yang disetujui, semakin besar anggarannya, maka semakin besar pula honor masing-masing pegawai, begitu pula sebaliknya. Dalam pembagian honor masing-masing pegawai besarannya sangat sedikit, dimana dalam pembentukannya terdiri dari ketua, administrasi, teknis dan anggota.

Kompensasi Non Finansial

a. PromosiJabatan

Penilaian dari pimpinan diharapkan objektif dalam mendukung karier pegawai untuk promosi jabatan dan secara reguler pimpinan dapat mengajukan usulan bagi pegawai yang sudah memenuhi persyaratan untuk dipromosikan ke jenjang yang lebih tinggi, disamping itu pegawai tersebut perlu menyiapkan beberapa berkas yang diperlukan, juga mereka diikutsertakan mengikuti beberapa diklat, ijin belajar dan lain-lain.

Selain itu, agar pegawai lebih maju dan berkembang serta menghindari kejenuhan dalam bekerja, pegawai mengharapkan adanya rotasi pekerjaan paling tidak setiap per-triwulan, agar semua pegawai mengetahui dan menguasai seluk beluk pekerjaan secara keseluruhan, sehingga jika ada masyarakat yang biasanya mengurus pelayanan dikantor ini, setiap pegawai mampu menjawab hal yang ditanyakan masyarakat, karena selama ini pegawai biasanya menyerahkan urusan kepada bidang yang bersangkutan.

b. Askes (Jaminan Kesehatan)/ BPJS

Askes merupakan kartu berobat yang mana setiap bulannya penghasilan pegawai dipotong beberapa persen untuk dialokasikan pada jaminan kesehatan Askes untuk biaya berobat pegawai. Jika Askes tidak dijalankan sesuai dengan fungsinya, akibatnya pegawai akan mengeluhkan ketidakpuasan mereka dalam penggunaan kartu Askes, untuk itu peran Askes harus lebih diperbaiki lagi secara optimal. Pihak rumah sakit harus dapat membebaskan biaya berobat pegawai, serta tersedianya obat-obatan yang diperlukan di apotik rumah sakit, sehingga pasien (pegawai) tidak perlu membeli ke apotik lain dengan mengeluarkan biaya sendiri.

c. Dana

Pensiun

Dana pensiun yang didapat pegawai setiap bulan hanya berkisar $75 \%$ dari gaji pokok, meskipun setiap tahunnya terdapat kenaikan gaji, namun karena semakin meningkatnya perekonomian nasional, nominalnya masih dirasa kurang, akan tetapi dengan adanya dana pensiun paling tidak ada harapan pegawai untuk memiliki pendapatan dimasa tuanya. Harapan pegawai adalah pemerintah lebih memperhatikan nasib para pensiunan pegawai karena mereka dulunya telah ikut memberikan kontribusi bagi instansi berupa pikiran dan tenaga, kalangan pensiunan biasanya mendapatkan rafelan kenaikan gaji, gaji ke 13 terlambat dalam pencairannya dibandingkan pegawai aktif, 
untuk itu pemerintah perlu memperhatikan kalangan pensiunan pegawai agar tidak ada kesenjangan.

\section{Kesimpulan dan Saran}

1. KompensasiFinansial

Sebaiknya gaji yang diterima pegawai selama sebulan tidak hanya untuk memenuhi kebutuhan pangan dan sandang saja, tetapi dapat memenuhi tarap hidup pegawai, seperti : memiliki rumah yang layak, sarana transfortasi yang memadai berupa mobil, kendaraan dinas dan ada anggaran untuk rekreasi serta kesejahteraan sosial. Disamping itu, agar gaji dapat lebih ditingkatkan lagi persentasenya setiap tahun dari sebelumnya. Tunjangan yang diterima selama ini berdasarkan tabel antara tunjangan dan jabatan, tetapi kedepannya diharapkan tunjangan jabatan yang diberikan harus disesuaikan dengan beban kerja pegawai, hal ini dilakukan agar pegawai termotivasi bekerja lebih baik dan produktif.

Insentif biasanya diterima pegawai ketika melaksanakan proyek kerja dan dilaksanakan oleh instansi ini per-triwulan dalam setiap tahunnya. Berdasarkan besarannya honor yang diterima pegawai dalam suatu proyek kerja sudah sesuai dengan beban kerja pegawai dengan merujuk kepada Pedum (Pedoman Umum) yang mengatur, kesesuaikan pendapat tersebut memotivasi pegawai untuk berusaha meningkatkan produktivitas kerjanya sesuai dengan perintah yang diberikan pimpinan.

2. Kompensasi Non Finansial Pimpinan selama ini mendukung karier pegawai untuk promosi jabatan dan secara reguler pimpinan sudah mengajukan usulan bagi pegawai yang sudah memenuhi persyaratan dan dianggap loyal serta mempunyai produktivitas kerja baik.Jaminan berobat disatu sisi cukup meringankan biaya pengobatan pegawai, namun disisi lain jaminan berobat tersebut tidak sepenuhnya menjadi tanggung jawab Askes, karena masih banyak biaya sendiri yang harus dikeluarkan, terutama jika obat yang diperlukan cukup mahal serta harus membeli di apotik lain.
Salah satu motivasi seseorang melamar bekerja sebagai PNS dikarenakan adanya jaminan hari tua atau mendapatkan dana pensiun. Disaat kondisi fisik sudah tidak mampu lagi untuk bekerja produktif, kesehatan menurun, tentu seseorang menginginkan ada penghasilan setiap bulan tanpa harus bekerja meskipun pendapatannya rendah. Permasalahannya adalah minimnya penghasilan tersebut jika dibandingkan dengan perekonomian yang akan datang dan lebih rendah dari gaji pokok PNS, tentu pendapatan tersebut belum cukup untuk memenuhi kebutuhan para pensiunan.

\section{DAFTAR PUSTAKA}

Ardana, Komang, dkk, 2008, Perilaku Keorganisasian, Penerbit Graha Ilmu, Jakarta.

Mailiana, 2010, Pengaruh Kompensasi terhadap Peningkatan Kinerja Individu, Vol. 4, No : 2, Juli 2010, ISSN : 1907-8439.

Pribadiyono dan Arif, Risman, 2002, Behavioral Performance and Productivity Management, Untag Press, Surabaya.

Rivai, Veithzal, 2004, Manajemen Sumber Daya Manusia untuk Perusahaan, Penerbit PT RajaGrafindo Persada, Jakarta.

Robbins, Stephen P, 2003, Perilaku Organisasi, Jilid 1, Edisi Indonesia, Penerbit PT Indeks Gramedia, Jakarta.

Samsudin, H. Sadili, 2006, Manajemen Sumber Daya Manusia, PT. Pustaka Setia, Jakarta.

Sutrisno, Edy,2010, Budaya Organisasi, Edisi Pertama, Cetakan Kencana Prenada Media Group, Jakarta. 